\title{
On Aspect, Biaspectuality, and Tenses in the History of Polish
}

\author{
PÉTER PÁTROVICS*
}

ELTE BTK Lengyel Filológiai Tanszék, H-1088 Budapest, Múzeum krt. 4/D.

Department of Polish Studies, Eötvös Loránd University (Budapest)

Received: 23 June 2020 - Accepted: 25 August, 2020

Published online: 13 September 2021

(c) 2021 The Author

\section{ANNOTATION}

By common consent, one of the most characteristic categories of the Polish verb is aspect. There can be little doubt that the origin of the aspect category may lie in Proto-Slavic or much further back in the Proto-IndoEuropean language. It is a moot point whether the aspect was already a strong category in Proto-Slavic. Nonetheless, it is beyond dispute that the consequences of its emergence were far-reaching and took a relatively long time to clarify in the daughter languages. The various categories such as aspect, biaspectuality, and tense providing the main themes of the present paper were closely related and did interact, however, the essential effects of their interaction can only be identified by scrutiny.

In Old Church Slavonic, a certain degree of competition between the category of aspect and that of tense can already be observed, and this is also evident in Old Polish, in which tenses like the aorist and the imperfect were slowly falling into disuse. Their occurrence is quite rare even in the earliest Polish written records. In due course, the perfect tense gained ground and the pluperfect became almost completely obsolete. In Modern Polish, the latter only serves to archaize literary texts. In the further stages of development, the aspectual opposition also extended to the future tenses thereby affecting the entire Polish tense system. Also, in the aspect-tense system of the Modern Polish language, the tendency of the category of aspect to prevail over the category of tense together with the gradual decline in the number of biaspectual verbs, still common in the 16th century, seems to be quite clear.

Most of the originally biaspectual initial verbs were later perfectivized by means of prefixes. Thus, the simple verbal bases and their perfectivized derivatives could establish an aspectual partnership. In the case of verbs with foreign roots, the prefix $z$ - / s- played a pivotal role in perfectivation, while other prefixes such

* Corresponding author. E-mail: patrovics.peter@btk.elte.hu 
as $z a$ - and $p o$ - had a less important role. The process of perfectivation in Polish was so extensive that only few biaspectual verbs remained free of the opposition of aspect as reminders of the fact that the development of this category is still an ongoing process. This is also shown by the more recent biaspectual verbs with borrowed roots for which it can be anticipated that they will form their perfective counterparts soon.

The paper concludes that the amount of verbs with an aspectually uncertain status is likely to be a reliable indicator of the development of the aspect category for the earlier periods in the history of the Polish language. An important role in this may play the diachronic corpus-based investigation, which, though for a long time considered a stepchild of Slavic aspectual research, may still help to clarify a number of issues related to the category of aspect.

\section{KEYWORDS}

Polish verbal aspect, biaspectual verbs, perfectivation, tenses, Old Polish, aspectuality, prefixation, verbal categories, aspectual pairs

The Slavic verbal aspect having Indo-European roots in its present form is already a uniquely Slavic linguistic phenomenon (PÁtrovics 2004a: 78-91). Therefore, it would be no exaggeration to say that the statements which generally apply to the development of the Slavic verbal aspect as a whole, apply to the development of the Polish verbal aspect, too. ${ }^{1}$ In Modern Polish, like in other Slavic languages, prefixation as pisać 'to write' $\rightarrow$ napisać 'to write down' (perfectivation) and suffixation as przepisać 'to write' $\rightarrow$ przepisywać 'to write (often)' (re-imperfectivation) can be mentioned as the principal linguistic means used for the expression of aspectual meanings. It can be observed, however, that in the earlier periods of the history of the Polish language, some tenses of the preterit also had an aspectual value. ${ }^{2}$ This seems to be confirmed, for example, by the following Old Polish quotations, in which the verbs iść 'to go', wieść 'to carry', and nieść 'to carry', being clearly imperfective in Modern Polish, have a perfective meaning (WIJK 1962: 247). The aforementioned verbs appear in the quotations below in either the form of aorist ${ }^{3}$ or that of perfect:

Posadzi dzeyczyo pod drzewem... y gydze precz y szyødze od nyego na dostrzelenyu ['So she put the child down under a shrub, and then went and sat down about a bowshot away'] (Biblia Królowej Zofii, Gen XXI, 5).

A gdisz wyedze gy na wirzch gori Fegor... powye gemu Balaam ['So he took Baalam to the top of Peor... Balaam then said to him'] (Biblia Królowej Zofii, Num XXIII, 28).

1 Still, we cannot cast all Slavic languages in the same mould as some of them, especially the South Slavic languages, followed a different path of aspectual development than the East or the West Slavic ones. In several modern South Slavic languages, though to varying degrees, many tenses of the preterit, also known to Old Church Slavonic, have been preserved, while the category of aspect is also present. In Modern Bulgarian, for example, the category of tense and that of aspect are closely interwoven (STAMBOLIEVA 2008: 59).

2 Inspired by D. R. Dowty and also referred to by M. Egg, used here in a somewhat different sense (cf. DowTY 1979, EGG 1994: 14-16).

3 A tense of the preterit, characteristic of the system of Old Church Slavonic (and of some modern IndoEuropean languages), positively marked for temporal boundedness. 
A oni powiedzieli: „iz go Panu potrzeba”. I wiedli je do Jezusa. I... wsadzili... ['They answered: "The Master has need of it". So they brought it to Jesus... and threw...'] (Biblia Wujka, Lk XIX, 34-35).

...przygedze Ezau, nawarzyw karmyey s swego lowu, a nyesse oczczu. Y rzece... [‘...Esau came, with his catch prepared a dish and brought it to his father (to eat). And said...'] (Biblia Królowej Zofii, Gen XXVII, 30). ${ }^{4}$

Zawstydził się Faeton i sromem gniew zrazit, / Niósł potym matce, czym go Epafus naraził ['Phaeton was ashamed of himself and hid his anger in his shame, then he took to his mother what Epaphus had infuriated him with'] (Żebrowskiego przeobrażenia Owidyuszowe, 25). ${ }^{5}$

Instead of the verbs highlighted in bold in the above quotations, the perfect forms of prefixed verbs should be used everywhere in Modern Polish, cf.: gydze $\rightarrow$ poszła 'went'; wyedze $\rightarrow$ przywiódł / przyprowadził 'took'; wiedli $\rightarrow$ przyprowadzili (Jezusowi) 'brought (him to Jesus)'; nyesse $\rightarrow$ przynióst 'brought'; nióst $\rightarrow$ przynióst 'brought.' ${ }^{6}$ The monodirectional verbs of motion in the above quotations were often used in a perfective meaning in Old Polish, cf.:

...zaczerwieniawszy sie od wielkiego wstydu szedt (= 'poszedł') $i$ obiesit sie ['...he blushed in great shame, went, and hanged himself’] (GLICZNER 1558: G5).

Krol gdy się dowiedział, iż corka uciekła, ...domiślił się, iż za morze jachała (= 'pojechała') ['When the king learned that his daughter had fled, ...he thought she had gone overseas'] (SKARGA 1780: 487).

Jużeś leciat (= 'poleciał') za morze, Gąsko, jużeś w dole ['You've flown, Gąsko, overseas, you've been down'] (KochanowsKi 1584: 130).

...iż ji ostrzegt, aby bieżat (= 'pobiegł') co najdalej ['....and he warned him to run as far as he could'] (Liber maleficorum 1548: 141).

The structures in which a single verbal base occurs together with the adverb precz meaning 'away, aside' are also worthy of note, cf.:

...żorawie czując zime, precz lecieli ['...the cranes, feeling the winter, flew away'] (KochaNOWSKI 1586: 15).

...najadszy sie i napiwszy, podziękowawszy szli precz ['...after they had eaten and drunk enough, they thanked and left'] (BIELSKI 1551: 342v).

4 The English equivalents of the biblical texts are based on The New American Bible. New York: Catholic Book Publishing, 1991.

5 The English equivalent of the above text is based on Ovid's Metamorphoses translated by Ian Johnston (http:// johnstoniatexts.x10host.com/ovid/ovidtofc.html).

6 N. van Wijk points out that Linde used the form doniósł pfv. instead of niósł ipfv., when rendering the above line (WIJK 1962: 247). 
The adverb precz did not yet have a pejorative meaning in Old Polish as in Modern Polish. ${ }^{7}$ It only stressed that the completion of the action denoted by the verb has been finalized. In the case of the expression iść precz, for example, the role of precz was later taken over by the prefixed derivative pójść. In the above quotations, the perfective meaning of the verbs cannot be traced solely to the element of determinativeness in their semantic structure, the meaning of the aorist and the perfect also play a significant role.

In the course of later development, determinativeness works in such a way that in some cases, prefixed verbal roots with originally determined meaning become the perfective members of the aspectual opposition, while forms with undetermined meaning (i.e. unidirectional verbs of motion) become the imperfective members of the aspectual partnership, cf.: przy + nieść pfv. : przy + nosić ipfv.; przy + wieść pfv. : przy + wodzić ipfv.; przy + wieźć pfv. : przy + wozić ipfv. 'to bring here'. However, as N. van Wijk also points out, this is the last stage of the process, a kind of closing act, during which in Polish, like in other Slavic languages, pairs of verbs consisting of imperfective and perfective members establish aspectual oppositions (WIJK 1962: 248). Prefixation is one of the processes by which aspectual pairs were formed in Slavic languages, including Polish. The other and much older one is the replacement of thematic suffixes, cf.: dać pfv. : dawać ipfv. 'to give'; paść pfv. : padać ipfv. 'to fall'; wrócić pfv. : wracać ipfv. 'to get / go / come back, return'. The first of the aforementioned processes played a major role in the fact that over time, the number of Polish biaspectual verbs, ${ }^{8}$ which was still very high in Old Polish, decreased significantly. In his study, ${ }^{9}$ J. Perlin estimates the total number of biaspectual verbs in Modern Polish at 73, with only 8 having an original Polish root (PERLIN 2010: 165).

Contrary to N. van Wijk's view (WIJK 1962: 247-248), however, the verbs in the above quotations cannot be regarded as fully biaspectual since the perfective meaning of the monodirectional verbs of motion such as iść 'to go', jechać 'to go, travel', lecieć 'to fly', and bieżeć 'to run' only exists in few forms (mostly in the aorist and in the perfect) but is missing in the present tense. The Mączyński Dictionary as well as other Latin-Polish dictionaries like the Calepino Dictionary or the Volckmar Dictionary record the imperfective meaning of some formally perfective Polish verbs: replico, dissolvo ${ }^{10}$ - odplątam, rozdziergam, fałdy rozsypuje, rozpuszczam (MĄczý́sKi 1564: 305c), dispumo - odszymuje (CALEPINo 1590: 332a), aduror, coloror - ogorzeje (VolCKMAR 1688: Ooo4v.).

\footnotetext{
7 Cf. Modern Polish phrases precz z mego domu! 'out of my house!', precz z prezydentem! 'down with the president!', etc.

8 We consider verbs as biaspectual if their present forms are able to express a future action, too, with the same meaning. A suitable test to determine the biaspectuality of a verb may be whether the verb can be used in the meaning of indefinite future (cf.: Może kiedyś ofiaruję ci to. 'I may offer this to you sometime.'), for it is well known that definite future actions, the occurrence of which is beyond doubt, can be expressed in Polish by the present forms of imperfective verbs, cf.: Jutro wyjeżdzam, a pojutrze wracam. 'I'm leaving tomorrow, I'll be back the next day.' The present forms of imperfective verbs, however, cannot denote an indefinite future. Forms like ${ }^{*}$ może kiedyś idę, lecę 'maybe someday I will go, run' are not semantically acceptable in Polish. J. Perlin, who discusses the issue of the number of Polish verbal aspects (PerLIN 2005), draws attention in a subsequent paper to the difficulties of determining the biaspectual status of a verb associated with the possibility of formation of anterior adverbial participles such as importowawszy (?), potrafiwszy (?), urlopowawszy (?) in Polish (PerLIN 2010: 165).

$9 \quad$ Biaspectuality is perhaps not one of the most high-profile topics in Polish aspectology, although some studies address the issue (cf. JANOWSKa 2018, PerLin 2010, WilCZEwSKA 1993). In his recent volume on the Polish verbal aspect, M. Łaziński also touches on the problem of biaspectuality (ŁAZIŃsKi 2020: 79-80).

10 In Latin dictionaries, verb headwords always occur in their singular first-person declarative forms.
} 
Verbs like odplatać 'to untie, undo, rozdziergać 'to untie, undo, unravel', odszymować 'to skim off', and ogorzeć 'to get sunburn' in the aforementioned entries cannot be considered imperfective in Old Polish. They must be considered biaspectual, which is also in line with T. Skulina's standpoint (SKulina 1959). The number of biaspectual verbs in 16th-century Polish ${ }^{11}$ was still quite large compared to the current state and the vast majority of them were of Latin origin, cf.:

approbować 'to approve'; deklarować (ogłosić : ogłaszać) 'to declare'; deputować 'to depute'; arendować (zajać : zajmować prawnie wartość materialna) 'to lease'; dedykować 'to dedicate'; derogować (uchylić: uchylać przepis prawny) 'to derogate'; egzaminować (sprawdzić : spraw$d z a c ́$ ) 'to examine'; egzekwować 'to execute'; ekskludować (wyłaczyć : wyłaczać) 'to exclude'; ekscypować się (wynaleźć : wynajdować powody prawne do przełożenia terminu sprawy) 'to find legal reasons to postpone the deadline'; ferować 'to take, carry'; imprymować (drukować) 'to print'; kontentować się 'to content oneself with'; kreować (mianować) 'to create, name as / for'; kwitować, moderować 'to moderate'; opponować się 'to oppose'; konfirmować (potwierdzić : potwierdzać) 'to confirm'; ekstendować (rozszerzyć : rozszerzać) 'to extend'; kanonizować 'to canonize'; konkludować (postanowić : postanawiać) 'to conclude'; konsygnować (zapisać : zapisywać) 'to consign'; kommunikować (uzgodnić : uzgadniać / przyjać : przyjmować komunię) 'to harmonize, go to Communion'; kondonować (przebaczyć : przebaczać) 'to forgive, pardon'; konferować (przekazać : przekazywać na własność) 'to confer'; konsyderować (rozważyć : rozważać) 'to consider'; ordynować (ustanowić : ustanawiać, uformować : formować szyk wojskowy) 'to order’; elucydować (objaśnić : objaśniać) 'to elucidate'; adhortować (napomnieć : napominać) 'to hint'; inwitować (zaprosić : zapraszać) 'to invite'; imitować (wziać : brać za wzór) 'to imitate'; annotować (zapisać : zapisywać) 'to annotate'; inserować (wpisać : wpisywać do ksiag urzędowych) 'to insert'; kommendować (zalecić : zalecać) 'to commend'; forować (wyprawić : wyprawiać) 'to send' (Doroszewski 1926).

The fact that the vast majority of verbs with borrowed roots were biaspectual in Old Polish can be explained by the fact that they were not fully part of the Polish verb and aspect system, which at that time was not yet crystallized. Most of the above verbs are now obsolete or part of scientific or legal terminology. However, there are some of them that are still considered biaspectual. Examples include kanonizować 'to canonize', annulować 'to annul', ewakuować 'to evacuate', and ratyfikować 'to ratify'. Others belong to the group of monoaspectual verbs being imperfective such as arendować 'to lease' and ferować to take, carry', the frequency of which is very low in Modern Polish. However, most of the originally biaspectual verbs were later perfectivized in the history of Polish by means of prefixes, ${ }^{12}$ and now the prefixed derivative and its source verb (simplicium) establish an aspectual partnership. ${ }^{13}$ The most common prefix involved in perfectivation is the prefix $z$ - / s-, cf.:

11 A. Janowska points out that "the 16th century is the period of intensified processes of assimilation of foreign forms in Polish" (JANOwsKa 2018: 527).

12 S. Oertle virtually identifies Slavic prefixation with perfectivation (OerTLE 2016: 59). For the function of Polish aspectual prefixes, see ŁAZIŃsKI 2011.

13 As L. Jászay remarked in a paper on the biaspectuality of Russian verbs, the biaspectuality of a simple verbal base is not always lost with prefixation. There are even possible cases in which the perfective meaning of a simple verbal base is preserved for a longer period of time (JÁszAY 2017: 51). The situation is similar in Modern Polish, in which the still biaspectual aresztować exists alongside its prefixed and clearly perfective counterpart zaaresztować, cf.: aresztowano go vs. zaaresztowano go 'he was arrested'. 
zdegradować się : degradować się 'to demote, degrade'; zdyspensować : dyspensować 'to dispense'; zimitować : imitować 'to imitate'; zlustrować : lustrować 'to vet, inspect'; zobligować : obligować 'to oblige / obligate'; skorrygować : korrygować 'to correct, proofread'; sfingować : fingować 'to fix, rig'; skasować : kasować 'to punch, erase, delete'; skomponować : komponować 'to compose'; skonfederować się : konfederować się 'to confederate'; skonfiskować : konfiskować to confiscate'; skwitować : kwitować to acknowledge receipt of sg.'

After the prefix $z$ - / s-, the prefix $z a$-follows in the frequency line:

zaaprobować : aprobować 'to approve'; zaaresztować : aresztować 'to arrest'; zadedykować : dedykować to dedicate'; zadeklarować : deklarować 'to declare'; zakonkludować : konkludować 'to conclude'; zaordynować : ordynować 'to order'.

The prefix $z a$-is followed in order by the prefixes $u$ - and po-, and finally, by the prefix prze-:

ufundować : fundować 'to found, establish'; ukontentować : kontentować 'to content oneself with'; wyegzekwować: egzekwować to execute'; wykreować: kreować to create, name as / for'; pokwitować : kwitować 'to acknowledge receipt of sg'; przeegzaminować : egzaminować 'to examine' (Guiraud-Weber 1998, PÁtrovics 2015: 198).

The number of biaspectual non-prefixed verbs is very small in Modern Polish, in which only five, ciać 'to cut', kazać 'to tell / order to do', pasować 'to suit, match', razić 'to dazzle, offend', and tchnać 'to breathe' have been preserved in their original form. An iterative, ofiarowywać has been formed from the originally biaspectual verb ofiarować 'to donate, offer, sacrifice' but it also has a prefixed derivative zaofiarować (się) establishing an aspectual partnership with its imperfective counterpart ofiarować (się). Most of the formerly biaspectual verbs have been perfectivized by means of prefixes following a pattern similar to ofiarować, cf.: zamianować pfv. : mianować ipfv. 'to name as / for' or zranić pfv. : ranić ipfv. 'to wound'. Like ofiarować, the verb darować to present', too, has an iterative form darowywać but there is also a perfective derivative podarować combined with the prefix po-. As a result of this derivational process, a triplet like darować ipfv. / pfv. : darowywać ipfv. : podarować pfv. has been formed. The once biaspectual mienić (się) 'to change' has fallen into disuse, the pairs zmienić sie pfv. : zmieniać się ipfv. and wymienić pfv. : wymieniać ipfv. are now used in similar meanings. The verb oględać 'to see, look at, watch' (its today's form is ogladać), which in Old Polish was biaspectual but occurred mainly in a perfective meaning, underwent intricate changes. The verb ogladać in Modern Polish is clearly imperfective, its perfective counterpart is the suppletive obejrzeć. The original imperfective counterpart of the latter verb was obzirać, which fell into disuse in the meantime. (Be reminded, however, that the verb obzirać sie can still be found in the Linde Dictionary, cf. SJPL 3: 430.) As a perfective counterpart of ogladać, though quite rarely, the verb oględnac $c^{14}$ is also used (WILCzewsKa 1993). The 16th-century Polish biaspectual verbs frymarczyć 'to hawk', klaćc 'to curse', and lac się 'to lie down' are now imperfective, while rzec 'to say' has clearly become perfective by now. The biaspectual verb wydatkować 'to spend' also recorded in most of 20th-century Polish dictionaries was formed not too long ago.

14 The perfective verb form ogląnaqc, along with several other similar forms, is considered dialectal. Regarding its status and usage in Modern Polish, see Bralczyk 2009: 169. 
During the further development of the Polish aspect category, the majority of biaspectual verbs joined either the group of perfective or that of imperfective verbs. It was a common phenomenon in doing so that an originally biaspectual verb formed an aspectual opposition with its prefixed derivative. The course of this hitherto productive process triggered by the pressure imposed by the system is that the verb to which the prefix is added occurs more and more often in a perfective context until eventually this usage becomes exclusive. This seems to be supported by the fact that prefixed verbs may also have been used as biaspectual at an earlier stage in the history of the Polish language but this is not possible in Modern Polish. Such originally biaspectual verbs in Modern Polish belong to the group of either imperfective (e.g. nachylać się 'to bend down, lean', obmaczać 'to soak') or perfective verbs (e.g. odstrzelić 'to retort, shoot back', obstawić 'to cordon off, surround'). The verb niedostyszeć deserves special attention since in the meaning 'to be hard of hearing, it can only be imperfective, cf.:

...gdy kto nie dosłyszy, tedy żołć jego wołu z moczem kozim zmieszana, wlana w uszy poma$g a \ldots$ ['...if someone is hard of hearing, then ox-bile mixed with goat urine be poured into his ears to help...'] (FALimirz 1534/IV: 5b).

In the meaning of 'hardly heard', however, it can only be perfective, cf.:

Ostatniego nieborak nie dostyszat słowa ['The poor thing could barely hear the last word'] (KochanowsKi 1561: 76).

Based on the above examples, it seems appropriate to treat niedostyszeć and niedostyszeć as two separate verbs. Only few Polish verbs (e.g. aresztować 'to arrest', potrafić 'to be able to do') ${ }^{15}$ generally regarded as biaspectual and mainly with borrowed roots ${ }^{16}$ remind us that the evolution of the Polish aspect category is still an ongoing process which needs to be investigated in the context of many other factors. ${ }^{17}$

In some Slavic languages, the reduction in the number of biaspectual verbs and the development of the aspect category are accompanied by a collapse of the once complex Slavic tense system. ${ }^{18}$ The simplification of the Old Polish tense system mainly affects the forms of the aorist and

15 Be reminded that several of the aforementioned verbs already have perfective (or, on the contrary, secondary imperfective) counterparts, such as zaaresztować (zaaresztowywać) (see JADACKA 2013: 89). The verb mianować to name as / for' is classified as imperfective by some dictionaries (see SPP 1994: 335) but the Concise Dictionary of the Polish Language edited by E. Sobol classifies it as biaspectual (MSJP 1995: 433).

${ }_{16}$ J. Perlin points out that Polish native speakers also consider the biaspectual koronować 'to crown' and urlopować 'to be on leave / holiday' to be verbs with original Polish roots but in fact, they are also borrowings (PERLIN 2010: 165).

17 This is also shown by the more recent biaspectual verbs with borrowed roots such as kamerować to record on videotape', mopować 'to mop / wipe up', and spoilerować 'to spoil', which are expected to form their prefixed perfective counterparts soon (BURKACKA 2018: 21). Slang also provides several examples similar to the above, e.g. guglać 'to google', lajkować 'to like', czekować 'to check', czitować 'to cheat', densować 'to dance', fristajlować 'to freestyle', hajpować 'to hype', hejtować 'to hate', spikować 'to speak', szpilić 'to play' < Germ. spielen, szrajbać 'to write' < Germ. schreiben (PACHOwICZ 2018: 53-55).

18 Although L. Jászay accepted to some extent the possibility of inverse proportionality between the developed aspect system and the complex tense system of a given language, he also made some critical comments on my previous findings (cf. KréKITs-Jászay 2008: 163, PÁtrovics 2000, РÁtrovics 2004b). 
the imperfect ${ }^{19}$, the occurrence of which is quite rare even in the earliest Polish written records. The total number of aorist and imperfect forms in the literary remains of the Polish language does not exceed 26. The following list shows the numerical occurrence of archaic verb forms in each of the early literary remains of the Polish language:

Kazania Świętokrzyskie [Holy Cross Sermons] - 8;

Psałterz Floriański [St. Florian's Psalter] - 13;

Psałterz Puławski [Puławy Psalter] - 2;

Zapiska sądowa z r. 1401 [Court Record from 1401] - 2;

Biblia szaroszpatacka / Biblia Królowej Zofii [The Sárospatak Bible or the Bible of Queen Sophia $]^{20}-1$.

In other linguistic records, only the obsolete preterit forms of the verb być 'to be' occur sporadically. It is the only Polish verb whose aorist forms have been preserved in its entire paradigm, cf.: bych, by, by, bychom, byście, bycha. The situation is somewhat complicated by the fact that in Old Polish, the ending - cha has become uniformly common in both the aorist and the imperfect third person forms of the plural. ${ }^{21}$ Similarly, in the case of singular first-person verb forms, it is not always possible to distinguish aoristic forms from imperfect forms, cf.: OChSlav. imperfectum viděach 'saw' $\rightarrow$ OPol. widziech; OChSlav. aorist viděch $\rightarrow$ OPol. widziech (RosPond 1979: 306). In Old Polish, only the forms molwiach 'was speaking', siedziesze 'was sitting', biesze 'was', motwiasze 'was speaking', wychadzasze 'was going out', błogosławiacha 'were blessing', and biecha 'were' can be considered unambiguously imperfect forms, whereas the forms motwich 'spoke', pospieszycha 'hurried', and poczęchą 'conceived' are clearly aoristic. In the case of widziech 'saw / were seeing', zapłakachq 'began to cry / were crying', wzdacha 'rose / were rising', poklinacha 'swore / were swearing', szukacha 'sought / were seeking', łuczacha 'glowed / were glowing in the dark', potępiacha 'condemned / were condemning', przysięgacha 'swore / were swearing', mijacha ' passed / were passing', idziechq 'went / were going', wynidziechą 'went out / were going out', ukradziecha 'stole / were stealing', chwalecha 'praised / were praising', it is not possible to decide whether one is dealing with the forms of the aorist or those of the imperfect (KLEMENSIEwICZ 1961: 118). Z. Klemensiewicz, T. Lehr-Spławiński, and S. Urbańczyk add furthermore that it is not an easy task to decide whether one is dealing with aorist forms, or whether only the present third-person forms of the verb are included in the meaning of historic present in a given text. This is because the singular third-person forms of the Old Polish verbs coincided with the aoristic forms after the endings $-t b /-t s$ had been dropped. The text below illustrates this:

19 A tense of the preterit, characteristic of Old Church Slavonic (and of some modern Indo-European languages), negatively marked for temporal boundedness.

${ }_{20}$ The first name refers to the place in Northern Hungary (Sárospatak), where the linguistic record was found, the second name refers to the wife of the one-time King of Poland, to Queen Sophia, for whom the Bible translation was made.

${ }^{21}$ However, in some 15th-century linguistic records, e.g. in 15th-century Sermons (Kazania $z$ XV w.) and Przemyśl contemplations (Rozmyślania przemyskie), the byszę form of the aorist of the verb być 'to be' has also been preserved, cf.: abyszø gy thrzimali = abysze ji trzymali 'to keep (them)'; abyszya mnożyli = abyszę mnożyli 'to multiply (it)'. 
A gdyż tak szedł Tobiasz, a psek bieżał jego za nim, tedy pirwy nocleg miałasta podle rzeki Tygrys. A gdyż wynidze Tobiasz chcąc swe nogi umyć w rzece, wysunq̨wszy się jedna wielika ryba chcac ji połknąć. Jejże się Tobiasz użasł, pocznie wołać wielikim głosem, rzekąc: "Pomoż mi, panie, idzieć na mię ryba." I rzecze anjot: "ufaci ją za skrzele, wyciagni k sobie!" A gdyż to uczyni, wyciagnie ja na suszą; i pocznie się ryba miotać przed nogi jego. I rzekł mu anjoł... (Biblia szaroszpatacka, quoted by KLEMENSIEwICZ et al. 1955: 369).

'...the dog followed Tobiah [out of the house] and went with them. The travellers walked till nightfall and made camp beside the Tigris River. Now, when the boy went down to wash his feet in the river, a large fish suddenly leaped out of the water and tried to swallow his foot. He shouted in alarm. But the angel said to him, "Take hold of the fish and don't let it get away!" The boy seized the fish and hauled it up on the shore... The angel then told him...' (OT, Tobit 6,1-5).

Nor does the aspect of verbs always provide guidance on the definition of verb tenses. Although in Old Polish, the imperfect was mostly formed only from imperfective verbal bases, the aorist could be formed from both imperfective and perfective verbal bases (KLEMENSIEwiCZ et al. 1955: 24).

$Z$. Stieber points out that, in addition to the primary future-time meaning of singular third-person forms of perfectives (e.g. wejdzie 'goes in', krzyknie 'shouts', przyskoczy 'jumps [to me]'), a secondary, preterit meaning is also possible in Polish. He mentions as an example Wacław Potocki’s 17th-century epic poem Wojna chocimska, in which a sentence like "na takie argumentum Żurawski krząknie" ['Żurawski grunts / grunted at this argument'] occurs. Similar verb forms can also be found in some works written by the famous 19th-century poet Adam Mickiewicz. ${ }^{22}$ Stieber sees the cause of the phenomenon in the fusion of the aorist and the forms of the present, and adds that in Modern Polish, these forms are beginning to lose their secondary preterit meaning (STIEBER 1979: 230). Z. Klemensiewicz, T. Lehr-Spławiński, and S. Urbańczyk trace back to the development of the aspect system that the aorist and the imperfect in Polish fell early in disuse, which eventually led to systemic changes. As a result, the once complex tense system collapsed and thus, in part, the aspect category began to convey meanings previously expressed by the aorist and by the imperfect. ${ }^{23}$

An important reason for the fact that the imperfect and the aorist became obsolete was the development of complementary categories of the verb with the same real meaning and opposing each other with an imperfective and perfective aspect. The difference formerly expressed by the opposition of the imperfect, which expresses an action in progress in the past, and the aorist, which expresses a single action in the finite past, begins to express one complex form of the preterit so that the imperfect is replaced by the complex

\footnotetext{
22 “...wtem stójcie, stójcie - krzyknie stary zbójca..." [‘...stop, stop right away, the old bandit cries / cried’] (A. Mickiewicz: Powrót taty).

${ }_{23}$ The intricate interplay of the tense system and the aspect category in the case of Polish and other languages (German and French) is also pointed out by other linguists (cf. RosPond 1979: 304-305, VATER 2000).
} 
form of the past tense of imperfective verbs, the aorist through the complex past tense of perfective verbs. ${ }^{24}$

Linguistic records show that in the Polish-speaking area, forms of the perfect begin to replace synthetic verb forms very early on. ${ }^{25}$ It is a Polish peculiarity that the originally analytical perfect becomes synthetic as the short forms of the verb być 'to be' participating in the formation of the perfect as an auxiliary verb merge with the forms of the perfect participle; cf.przysiagt + jeśm $\rightarrow$ przysiagtem 'I have sworn', uczynili + jeście $\rightarrow$ uczyniliście 'you have done (it).2. ${ }^{26}$ This is, however, a purely formal thing which is irrelevant to the category of aspect.

Unlike the aorist and the imperfect, the pluperfect ${ }^{27}$ (czas zaprzeszły or czas przeszły podwójnie

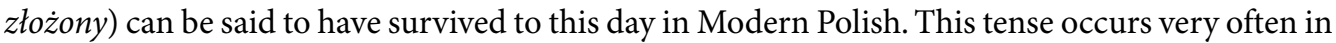
an early linguistic record called The Bible of Queen Sophia and in some court records (e.g. Zapiska sadowa $z 1394$ r.). As for the frequency of the occurrence of the pluperfect, the Gniezno Sermons (Kazania Gnieźnieńskie - KGn) occupy a special place since only this tense is used to denote past events in them. However, the general use of the pluperfect in this linguistic record is merely a stylistic trick (amplification) serving to increase the length of the text. In Modern Polish, the pluperfect is scarcely ever used, although it is mentioned in some Polish grammars (STEFAŃCZyK 1996: 137, Tікноміrova 1978: 94-95).$^{28}$ If this tense is used, it rarely indicates an action in the past that took place before another past action. The pluperfect in Modern Polish most often has only stylistic value since its original function has been taken over by the anterior adverbial participle (JADACKA 2013: 93). Stieber's following lines speak convincingly about how vague the meaning of this tense is in the minds of today's Polish native speakers:

The pluperfect is not used in modern spoken Polish. In my youth, I knew a person who would now be 112 years old and who used forms of the type widziałam była ['I had seen (it)']. However, I do not remember what the function of these forms was. But in the 19th century, many writers used the pluperfect, and some, though few, still use it today. ${ }^{29}$

24 „Ważną przyczyną ówczesnego zaniku imperfektu i aorystu był rozwój uzupełniających się wzajemnie systemów czasownika o tym samym znaczeniu realnym, a przeciwstawiających się sobie aspektem niedokonanym i dokonanym. Różnicę wyrażoną dawniej przez opozycję imperfektu, który mówi o czynności trwającej w przeszłości, i aorystu który mówi o czynności jednokrotnej, w przeszłości skończonej, zaczyna wyrażać jedna złożona forma czasu przeszłego, tak że imperfekt zostaje zastąpiony przez złożoną formę czasu przeszłego słów niedokonanych, aoryst zaś przez złożoną formę czasu przeszłego słów dokonanych” (KLEMENSIEwicz et al. 1955: 370).

25 Nonetheless, it is important to note that the collapse of the tense system in Polish was not a one-way process. In 15th-century Polish, new tense forms developed on the basis of the former aorist on the analogy of the endings of the conditional. Though these forms proved to be ephemeral and fell completely into disuse in the 17th century, they were widespread throughout the Polish-speaking area for almost two centuries, including the north-eastern periphery. Some remnants of these verb forms can still be found in the dialects of Little Poland and Silesia (Kurzowa 2007).

${ }^{26}$ Except for the singular and plural third-person forms, in which the forms of the verb być 'to be' were dropped very early, cf. otwodziła 'led away', królewat 'reigned', widziele oczy moi 'my eyes saw (it)', styszali 'they heard (it)' (Kazania Świętokrzyskie, the first half of the 14th century).

27 Opinions on the use of the pluperfect in Old Church Slavonic are divided (see VAILlAnT 1948 and SELISHCHEv 1952 among others).

28 Other Polish grammars, however, make no mention of the pluperfect (cf. PolAńsKI-NowAK 2011).

29 „We współczesnej polczczyźnie mówionej nie używa się czasu zaprzeszłego. W młodości znałem osobę, która by teraz miała 112 lat, a która używała form typu widziałam była. Jaka jednak była funkcja tych form, nie pamiętam. Ale w XIX w. wielu pisarzy używało czasu zaprzeszłego, a niektórzy, choć nieliczni, używają go i dziś”" (STIEBER 1979: 239). 
The pluperfect frequently occurs, for example, in the works of the early 20th-century Polish woman writer Maria Dąbrowska, cf.:

Ten kogom kochała mógł był nie wiem co robić... a ja za jeden uśmiech wszystko bym jemu przebaczyła ['The one I loved could have done, I don't know, anything... and I would forgive him everything for one smile’] (M. Dąbrowska: Noce i dnie).

In Modern Polish, the present forms of perfective verbs denote completed actions in the future (futurum proste). This tendency of development is known to the North Slavic, although traces of it can also be found in the South Slavic languages.

In Polish, the auxiliary verb być 'to be' and either the infinitive form of the imperfective verb or the perfect participle formed from the imperfective verb (futurum złożone II, futurum exactum) participate in the formation of the analytical future tense (futurum złożone I). This structure probably also developed in the North Slavic dialects and can be found in the earliest Polish written records (STIEBER 1979: 240, GóRECKA-ŚMIECH 1972). Structures formed using the infinitive are more common in earlier periods of the Polish language. In Modern Polish, both types of future tenses are used in the same role, and although there are some regional differences between the use of the two structures, one can rightly speak of their functional mixing (STIEBER 1979: 242). ${ }^{30}$

In the case of Polish, the development outlined above is in line with the general tendencies observed in the Slavic languages. With the development of the aspect category, the following linguistic changes took place: a) the number of originally biaspectual verbs decreased, in the semantics of such verbs either the meaning of imperfectiveness or that of perfectiveness became decisive; most of the originally biaspectual verbs (simple verbal bases) established an aspectual partnership with their perfective derivatives created by means of prefixes; b) the number of tenses decreased significantly; some of them, the originally synthetic ones (the aorist and the imperfect) became completely obsolete (there are no remnants of them in Modern Polish), while the use of the pluperfect was significantly reduced; the perfect tense gained ground and became an almost universal tense of the preterit, however, it became divided in form and function (for an imperfective and a perfective past tense); the aspectual opposition also extended to the future tenses thereby affecting the entire Polish tense system; over time, various modal meanings (e.g. possibility, permission, and obligation) were added to the aspect-tense forms of the Polish verb.

From the linguistic data presented in this paper, it emerges that diachronically there are often mutual connections between the complexity of the tense system and the aspect system of a given language. In the languages in which the once complex tense system is collapsed, its role is partly or entirely taken over by an emerging aspect category. Old Polish and Modern Polish can be a good example of these processes. Considering that the earlier periods of Slavic languages are often characterized by a relatively larger number of verbs with an aspectually uncertain status showing the underdeveloped character of the aspect category, there is good reason to assume that one could infer the degree of development of the aspect category, among other things, from the aspect value data of the verbal vocabulary of a particular Slavic language.

30 In his paper devoted to the problem, B. Dunaj claims that the use of the two structures is influenced by different factors. He adds furthermore that it would also be worthwhile to examine the extent to which the gender of speakers may play a role in the choice between the two structures. In addition to mentioning minor characteristic features of use, he concludes that structures with the participle form are somewhat more common in masculine personal form than in feminine or neuter gender (DUNAJ 1987). 
An aspect-based study of verb forms in the literary remains of the Polish language could provide a sound basis for this. However, determining the aspect value of the Old Polish verb forms, as discussed in this paper, can meet with considerable difficulties in some cases. It appears that the diachronic, corpus-based investigation of the Slavic verbal aspect, which in the case of Polish, not to mention other Slavic languages, has remained in the background so far, ${ }^{31}$ may also play an important role as a means of determining the extent to which the aspect category of a particular Slavic language was developed in different periods of its history. The reliability of the result is, however, always limited by the size and the quality of annotations of the corpus available from the given period.

\section{SOURCES}

BIELSKI 1551 = BIELSKI Marcin: Kronika wszytkiego świata. Kraków, 1551.

CAlePIno 1590 = CAlepino Ambrogio: Dictionarium undecim linguarum. Basel, 1590.

FALIMIRz 1534 = FALIMIRz Stefan: O ziołach $i$ mocy ich. Kraków, 1534.

GLICZner 1558 = Gliczner Erazm: Książki o wychowaniu dzieci bardzo dobre, pożyteczne i potrzebne. Kraków, 1558.

KochANOwsкi 1561 = KocHANowsкI Jan (1561): O śmierci Jana Tarnowskiego, kasztelana krakowskiego, do syna jego Jana Krzysztofa, hrabiego $z$ Tarnowa, kaszetalana wojnickiego. Kraków, 1561.

KochANOWSKi 1584 = Kochanowski Jan: Fraszki. Kraków, 1584.

Kochanowski 1586 = Kochanowski Jan: Pieśni. Kraków, 1586.

MĄCZYŃsKI 1564 = MĄCZYŃsKI Jan: Lexicon latino polonicum ex optimis latinae linguae scriptoribus concinnatum... equite Polono interprete. Königsberg, 1564.

SKARGA 1780 = SKarga Piotr: Żywoty świętych starego i nowego zakonu... zebrane i na polski język przełożone. Vilnius, 1780 .

Volckmar 1688 = Volckmar Nicolaus: Vierzig Dialoge oder lustige Arten zu reden von allerhand Sachen und Handeln in deutscher und polnischer Sprache zusammengebracht. Breslau, 1688.

\section{REFERENCES}

BRALCZYK 2009 = BRALCZYK J. Stowo o słowie. Warszawa: PWN, 2009.

BURKACKA 2018 = BURKACKA I. Słowotwórcze właściwości gniazd czasowników potocznych. In: Kultura komunikacji językowej 5. Kultura komunikacji potocznej w językach słowiańskich. Poznań: Wydawnictwo Nauka i Innowacje, 2018. 21-34.

Doroszewski 1926 = Doroszewski W. O znaczeniu dokonanym osnów czasownikowych (słownych) w języku polskim. Prace Filologiczne 10 (1926): 192-309.

Dowty 1979 = Dowty D. R. Word Meaning and Montague Grammar. Dordrecht: Reidel, 1979.

31 This can be traced back to several reasons. One of them is that diachronic corpora of particular Slavic languages have started to appear only very recently. However, among many other things, the fact that these corpora are small and not sufficiently annotated certainly plays a role, too. An exception is, for example, the recently lanced Korpus Barokowy of Polish (KorBa: http://korba.edu.pl/query_corpus). There is reliable information that a consistent annotation of aspect pairs is currently being developed for the Polish language in the DiAsPol250 project. 
Dunaj 1987 = Dunaj B. Czas przyszły czasowników niedokonanych w polszczyźnie - uzus i norma. Język Polski 1987/1-2: 9-19.

EGG 1994 = EGG M. Aktionsart and Kompositionalität. Berlin: Akademie Verlag, 1994.

GóReCKA-ŚMIECH 1972 = GóreCKA J., ŚMIECH W. Czas przyszły złożony w języku polskim. Rozprawy Komisji Językowej Łódzkiego Towarzystwa Naukowego 18 (1972): 11-38.

GUIRAUD-WebER 1998 = GuIRAUD-Weber M. La préfixation des emprunts verbaux en russe et en polonais. Revue des études slaves 70 (1998): 67-77.

JADACKA 2013 = JADACKA H. Kultura języka polskiego. Fleksja, słowotwórstwo, składnia. Warszawa: PWN, 2013.

JANOWSKA 2018 = JANOwsKA A. Właściwości derywacyjne pożyczeń czasownikowych w XVI wieku. Jazykovedný časopis 69 (2018): 527-535.

JÁszAY 2017 = JászAY László: Видовая «неопределенность» двувидовых глаголов как следствие морфемной немаркированности. Studia Slavica Hung. 62 (2017): 47-58.

KLemensiewicz 1961 = KLEMENSIEwiCZ Z. Historia języka polskiego I. Doba staropolska. Warszawa: PWN, 1961.

Klemensiewicz et al. 1955 = Klemensiewicz Z., Lehr-SpŁaWiński T., UrbańcZyK S. Gramatyka historyczna języka polskiego. Warszawa: PWN, 1955.

KRÉKITS-JÁsZAY 2008 = KRÉKITS József, JÁsZAY László: Szláv igeaspektus, különös tekintettel az orosz nyelvre [Slavic Aspect, with Special Emphasis on Russian]. Budapest: Akadémiai Kiadó, 2008.

Kurzowa 2007 = Kurzowa Z. Nowe uwagi o genezie i chronologii czasu przeszłego na -ch. In: Kurzowa Z. (red.) Z przeszłości i teraźniejszości języka polskiego. Kraków: Universitas, 2007.393-402.

ŁAZIŃsKi 2011 = ŁAZIŃski M. Polish aspectual prefixes, their order and functions. A study based on the National Corpus of Polish. Word Structure 4 (2011): 231-243.

ŁAZIŃsKI 2020 = ŁAZIŃsKI M. Wykłady o aspekcie polskiego czasownika. Warszawa: Wydawnictwa Uniwersytetu Warszawskiego, 2020.

MSJP 1995 = Mały słownik języka polskiego. Warszawa: PWN, 1995.

Oertle 2016 = Oertle S. Die slavischen Verbalpräfixe und Präpositionen. Polysemie und Grammatikalisierung. Herne: Gabriele Schäfer Verlag, 2016.

Pachowicz 2018 = Pachowicz M. Leksyka młodzieży. Tradycja, rozwój, kreatywność. Kraków: Księgarnia Akademicka, 2018.

PÁtrovics 2000 = PÁtrovics Péter: Aspektualität - Kasus - Referentialität - Temporalität. Ihre Relation im Deutschen und in den slawischen Sprachen. In: Aspektualität in germanischen und slawischen Sprachen. Poznań: UAM, 2000. 69-86.

PÁtrovics 2004a = PÁtrovics Péter: Az aspektus története és tipológiája [The History and Typology of Aspect]. Budapest: Akadémiai Kiadó, 2004.

PÁtrovics 2004b = PÁtrovics Péter: On case morphology and word order variation in Bulgarian and German. Anzeiger für slavische Philologie 32 (2004): 55-92.

PÁtrovics 2015 = PÁtrovics Péter: Functions of some Polish verbal prefixes. In: Beiträge zum 18. Arbeitstreffen der Europäischen Slavistischen Linguistik (Polyslav). (Die Welt der Slaven. Band 57.) Wiesbaden: Harrassowitz, 2015. 197-203.

Perlin 2005 = Perlin J. Ile jest aspektów w języku polskim oraz próba dowodu na fleksyjność opozycji dokonany / niedokonany? Biuletyn Polskiego Towarzystwa Językoznawczego 61 (2005): 49-58.

PerLIN 2010 = PerLIN J. Ile jest we współczesnej polszczyźnie czasowników dwuaspektowych? Linguistica Copernicana 3 (2010): 165-171. 
Polański-Nowak 2011 = Polański E., Nowak P. Najnowszy podręcznik gramatyki języka polskiego.

Kraków: Petrus, 2011.

RosPond 1979 = RosPond S. Gramatyka historyczna języka polskiego. Warszawa: PWN, 1979.

Selishснеv 1952 = Селищев А. М. Старославянский язык. Т. 2. Москва: «Учпедгиз», 1952.

SJPL = Słownik języka polskiego. T. 3. Lwów: Zakład Narodowy im. Ossolińskich, 1857.

Skulina 1959 = Skulina T. O aspekcie czasowników w słowniku Jana Mączyńskiego. Zeszyty Naukowe

UAM w Poznaniu 23 (1959): 109-152.

SPP 1994 = Słownik poprawnej polszczyzny. Warszawa: PWN, 1994.

Stambolieva 2008 = Stambolieva M. Building Up Aspect. A Study of Aspect and Related Categories in Bulgarian, with Parallels in English and French. Bern: Peter Lang, 2008.

StefAŃCZyк 1996 = StefańCZyK T. W. A mai lengyel nyelv leíró nyelvtana I. [A Descriptive Grammar of Modern Polish.] Debrecen: KLTE, 1996.

STIEBER 1979 = STIEBer Z. Zarys gramatyki porównawczej języków słowiańskich. Warszawa: PAN, 1979.

Тікномirova 1978 = Тихомирова Т. С. Польский язык. Москва: Издательство МГУ, 1978.

Vaillant 1948 = Vaillant A. Manuel du vieux slave. T. 1. Grammaire. Paris: Institut d'Études slaves, 1948.

VAter $2000=$ VAter H. Das deutsche Perfekt. Tempus oder Aspekt oder beides? In: Aspektualität in germanischen und slawischen Sprachen. Poznań: UAM, 2000. 87-107.

WIJк 1962 = Вейк Н. О происхождении видов славянского глагола. В кн.: Вопросы глагольного вида. Москва: «Иностранная литература», 1962. 238-257.

WiLczewska 1993 = Wilczewska K. Dwuaspektowość czasowników w polszczyźnie XVI w. Język Polski 1993/1-2: 19-29.

Open Access. This is an open-access article distributed under the terms of the Creative Commons Attribution 4.0 International License (https://creativecommons.org/licenses/by/4.0/), which permits unrestricted use, distribution, and reproduction in any medium, provided the original author and source are credited, a link to the CC License is provided, and changes - if any - are indicated. (SID_1) 